\title{
Emotional Intelligence among the Health Care Providers Working in a Tertiary Level Hospital
}

\section{Pramila Thapa ${ }^{1}$, Ramesh Bhatta ${ }^{1}$, Josana Khanal ${ }^{1}$, Anil Chaudhary ${ }^{1}$.}

${ }^{1}$ Nepal, Yeti Health Science Academy

Corresponding Author: Pramila Thapa, Nepal, 00977, Yeti Health Science Academy, pbrt426@gmail.com

\begin{abstract}
Emotional intelligence (EI) is the ability to be aware of and control one's emotions and empathize with others. EI is essential for the well-being of a health care provider and their professional practice. A health care provider's empathy is important in building a strong relationship with the patient which results in enhanced positive service outcomes. Emotional intelligence competence can be acquired through training and implementation in our own life. As every person is unique, he or she needs to learn concepts that will be suitable for him or her. The objective of the study is to assess the emotional intelligence among health care providers working in a tertiary level hospital and also to understand the association of emotional intelligence with demographic variables of work experience and age of health care providers working in a tertiary level hospital. A descriptive crosssectional research design was conducted in the Tertiary Level Hospital of Kathmandu District, Nepal to assess the emotional intelligence among health care providers. Through convenience non-probability sampling technique 100 health care providers were selected and to assess the status of emotional intelligence Standard Self-Report Emotional Intelligence Test (SSEIT) was used. Results of the study revealed that the highest forty per cent of the respondents have a low level of emotional intelligence and only thirty-two per cent of respondents have a high level of emotional intelligence. Lower in the level of EI among the health workers may be due to the lack of awareness on EI There was also significant association between the level of emotional intelligence with the respondent's age $(\mathrm{p}=0.003)$. which shows with the increasing age, individuals have different working exposures that improve in their maturity, which may support increasing the level of EI, and there is no significant association with respondent's working experience.
\end{abstract}

Key words: Emotional intelligence, stress, compassion, fatigue, interference, intervention.

\section{Introduction}

Emotional intelligence is the competency of health care providers working in a tertiary level hospital which helps to understand and regulate emotions of self as well as others (Goleman, 2001). There is a significant relationship between emotional intelligence, 
happiness and mental health in addition to making a contribution to achievement in maximum endeavours (Sasanpour, Khodabakhshi, \& Nooryan, 2012). It additionally performs an essential element in forming successful human relationships, establishing a therapeutic nurse-patient relationship (McQueen, 2004). Emotional intelligence and patient- centres care increasing stress as a part of health care policy and practice (Birks \& Watt, 2007). It may be taught, learned, and modified in medical care packages for better patient-doctor relationships (Basem Abbas Al, 2018).

\section{Materials}

There is a significant positive correlation between emotional intelligence and subjective well-being (Rema \& Gupta, 2021; Sánchez-Álvarez, Extremera, \& Fernández-Berrocal, 2016). There is an association of higher emotional intelligence with a positive mood and higher self-esteem (NS Schutte, JM Malouff \& Hollander, 2002). Nurses with higher EI will contribute to a more productive and harmonious work environment. There is a significant positive relationship between job performance and emotional intelligence (Li et al., 2021; Patrianus Khristian Smule, 2012). It did not differ significantly from clinical nursing experience and was positively significant with age (Intelligence, 2018). Four common paradigms; self-awareness, self-management, social awareness and relationship management are the main ingredients for increasing the well-being of health care providers. It helps to increase the quality and positive outcomes of personal and professional life (Raghubir, 2018). Intervention, in order to increase emotional intelligence, can be powerful in improving empathetic communication, clinical performance, the relationship between patient and health care providers, and improve clinical outcomes.

\section{Objectives}

To identify the level of Emotional Intelligence among health care providers.

To identify the association between emotional intelligence with selected sociodemographic variables of age.

To identify the association between emotional intelligence and working experiences.

\section{Research Methods}

A descriptive cross-sectional research design was adopted to conduct the study in the Tertiary Level Hospital of Kathmandu District, Nepal to assess the emotional intelligence among health care providers. The study includes convenience non-probability sampling techniques and 100 healthcare providers were included in the study. The dependent variable was emotional intelligence and independent variables were health background, age, gender, years of experience and training on EI. A Standard Self- Report Emotional Intelligence Test (SSEIT) was used to collect data. It comprises a self-report on a 5- point Likert scale: 1- strongly disagree, 2- disagree,3-neutral, 4- agree, 5-Strongly agree. It is a 
33-items Likert scale. It is a valid tool with internal consistency (Cronbach's alpha= 0.90) (Schutte et. al., 1998). For analyzing the study data, Statistical Package of Social Sciences (SPSS), descriptive statistics analysis (Frequency and Percentage) and Pearson Chi-Square test and Fisher's Exact Test was used to measuring the association between level of emotional intelligence with selected variables.

\section{Results}

Table no.: 1

Socio-demographic variables of respondents $\mathrm{n}=100$

\begin{tabular}{|l|l|l|}
\hline Variables & Frequency & Percentage (\%) \\
\hline Healthcare Provider & & \\
\hline Nursing & 60 & 60.0 \\
\hline Others Paramedical (Lab, Radiographer, HA \& Pharmacy) & 40 & 40.0 \\
\hline Age & & \\
\hline $18-27$ years & 9 & 9.0 \\
\hline $28-37$ years & 69 & 69.0 \\
\hline 38 years and above & 22 & 22.0 \\
\hline Gender & & \\
\hline Male & 21 & 21.0 \\
\hline Female & 79 & 79.0 \\
\hline Year of working experience & & \\
\hline $1-5$ years & 77 & 77.0 \\
\hline $6-10$ years & 14 & 14.0 \\
\hline $11-15$ years & 7 & 7.0 \\
\hline 16 years and above & 2 & 2.0 \\
\hline Emotional Intelligence Training Status & & \\
\hline No (not take any training on EI by the respondents) & 100 & 100.0 \\
\hline
\end{tabular}

Table no. 1 displays information about socio-demographic variables of the respondents and it revealed that the majority $(60 \%)$ of the respondents were nurses and $(40 \%)$ were paramedical staffs (i.e. Lab technologist, Radiographer, Health Assistant and Pharmacy). The majority (69\%) of the respondents were from 28 to 37 years of age whereas $22 \%$ of respondents were 38 years and above and 9\% respondents were from 18- 27 year group. The majority (79\%) of the respondents were female whereas the remaining $(21 \%)$ of the respondents were male. The majority $(77 \%)$ of the respondents had 1-5 years of work experience whereas a few (14\%) of the respondents had 6-10 years of work experience and only $(2 \%)$ of respondents had work experience of 16 years and above.. All the respondents 
who were included in the study had not taken any training related to emotional intelligence.

Table no.: 2

Level of Emotional Intelligence

$\mathrm{n}=100$

\begin{tabular}{|c|c|c|}
\hline Level of Emotional Intelligence & Frequency & Percentage (\%) \\
\hline Low & 40 & 40.0 \\
\hline Average & 28 & 28.0 \\
\hline High & 32 & 32.0 \\
\hline
\end{tabular}

Table no. 2 shows the level of emotional intelligence and revealed that the highest number (40\%) of respondents has a low level of emotional intelligence whereas $32 \%$ of respondents have a high level of emotional intelligence and whereas the rest (28\%) has an average level of emotional intelligence.

\section{Table no.: 3}

Association between Emotional Intelligence and Age

$\mathrm{n}=100$

\begin{tabular}{|c|c|c|c|c|c|}
\hline \multirow{2}{*}{ Level of EI } & \multicolumn{3}{|c|}{ Age } & \multirow{2}{*}{ Total } & P value \\
\cline { 2 - 4 } & $18-27$ & $28-37$ & 38 and Above & & \multirow{2}{*}{0.003} \\
\hline Low & $5(12.5 \%)$ & $20(50 \%)$ & $15(37 \%)$ & $40(100 \%)$ & \\
\hline Average & $2(7.1 \%)$ & $25(89.3 \%)$ & $1(18.8 \%)$ & $28(100 \%)$ & \\
\hline High & $2(6.2 \%)$ & $24(75 \%)$ & $6(18.8 \%)$ & $32(100 \%)$ & \\
\hline Total & $9(9 \%)$ & $69(69 \%)$ & $22(22 \%)$ & $100(100 \%)$ & \\
\hline
\end{tabular}

Table no.: 3 demonstrates the outcome of Chi-square and Fisher's exact test analysis carried out to find out the association between level of emotional intelligence and selected Sociodemographic variables which revealed that there is a significant association between level of emotional intelligence with respondent's age $(\mathrm{p}=0.003)$.

Table no.:4

Association between Emotional Intelligence and working experiences $\mathrm{n}=100$

\begin{tabular}{|c|c|c|c|c|}
\hline \multirow{2}{*}{ Level of EI } & \multicolumn{2}{|c|}{ Health care provider } & Total & P value \\
\cline { 2 - 4 } & Nursing & Others (Lab, Rad. \&HA) & & \multirow{2}{*}{0.501} \\
\hline Low EI & $21(52.5 \%)$ & $19(47.5 \%)$ & $40(100 \%)$ & \\
\hline Average EI & $18(64.3 \%)$ & $10(35.7 \%)$ & $28(100 \%)$ & \\
\hline High EI & $21(65.3 \%)$ & $11(34.4 \%)$ & $32(100 \%)$ & \\
\cline { 1 - 4 } Total & $60(60 \%)$ & $40(40 \%)$ & $100(100 \%)$ & \\
\hline
\end{tabular}


Table no.: 4 demonstrates the outcome of Chi-square and Fisher's exact test analysis being carried out to find out the association between level of emotional intelligence and working experience which revealed that there is no significant association between level of emotional intelligence with respondent's working experience $(\mathrm{p}=0.247)$.

\section{Table no.:5}

Association between Emotional Intelligence and Health care provider $\mathrm{n}=100$

\begin{tabular}{|l|l|l|l|l|l|l|}
\hline \multirow{2}{*}{ Level of EI } & \multicolumn{4}{|l|}{ Working Experience } & Total & \multirow{2}{*}{ P-value } \\
\cline { 2 - 6 } & $1-5$ yrs & $6-10$ yrs & $11-15$ yrs & 16 yrs and above & & \\
\hline Low EI & $31(77.5 \%)$ & $7(17.5 \%)$ & $2(5 \%)$ & 0 & $(100 \%)$ & 0.247 \\
\hline Average EI & $25(89.3 \%)$ & $2(7.1 \%)$ & $1(3.6 \%)$ & 0 & $(100 \%)$ & \\
\cline { 1 - 6 } High EI & $21(65.6 \%)$ & $5(15.6 \%)$ & $4(12.5 \%)$ & $2(6.2 \%)$ & $(100 \%)$ & \\
\cline { 1 - 6 } Total & $77(77 \%)$ & $14(14 \%)$ & $7(7 \%)$ & $2(2 \%)$ & $100(100 \%)$ & \\
\hline
\end{tabular}

Table no.: 5 demonstrates the outcome of Chi-square and Fisher's exact test analysis being carried out to find out the association between level of emotional intelligence and health care provider which revealed that there is no significant association between level of emotional intelligence and Health care $\operatorname{provider}(\mathrm{p}=0.501)$.

\section{Conclusions}

Emotional intelligence is fundamental to health workers practices. Concepts EI are central to nursing practices and affect critical thinking, decision making, quality of patient care and patient outcome (Bulmer, Profetto-mcgrath, \& Cummings, 2009). In addition, people with a higher level of emotional intelligence are found more successful as compared to those who were low at the emotional intelligence scale (Transactions, Sciences, \& Volume, 2013). Based on the finding the study concluded that forty per cent have a low level of emotional intelligence and only thirty-two per cent of respondents had a high level of emotional intelligence. Having low level of EI among the health workers may be due to the lack of awareness on EI.The study also shows a significant association between the level of emotional intelligence with respondent's age $(\mathrm{p}=0.003)$. Various studies also support the significant relationship between age and emotional intelligence (Chapman \& Jr, 2006; Date, 2020; Sliter, Chen, \& Withrow, 2013; Well-being, 2017). With the increasing age, individuals have different working exposures that improve in their maturity, which may support to increase their level of EI. Emotional intelligence contributes in the better performance of the staff, hence makes the workplace environment better. So, it is urgent and necesary to orient and train the health workers in the EI which will ultimately support the well-being of healthcare service providers and also the wellbeing of patients. 


\section{References}

1. Birks, Y. F., \& Watt, I. S. (2007). Emotional intelligence and patient-centred care. Journal of the Royal society of medicine, 100(8), 368-374.

2. Chapman, B. P., \& Hayslip Jr, B. (2006). Emotional intelligence in young and middle adulthood: Cross-sectional analysis of latent structure and means. Psychology and aging, 21(2), 411.

3. Li, X., Chang, H., Zhang, Q., Yang, J., Liu, R., \& Song, Y. (2021). Relationship between emotional intelligence and job well-being in Chinese clinical nurses: multiple mediating effects of empathy and communication satisfaction. BMC nursing, 20(1), 1-10.

4. McKenna, J., Webb, J. A., \& Weinberg, A. (2020). A UK-wide analysis of trait emotional intelligence in occupational therapists. International Journal of Therapy And Rehabilitation, 1-13.

5. McQueen, A. C. (2004). Emotional intelligence in nursing work. Journal of advanced nursing, 47(1), 101-108.

6. MK, R., \& Gupta, R. (2021). Emotional Intelligence and Subjective Well-being among Working Women. Journal of International Women's Studies, 22(6), 55-65.

7. Sánchez-Álvarez, N., Extremera, N., \& Fernández-Berrocal, P. (2016). The relation between emotional intelligence and subjective well-being: A meta-analytic investigation. The Journal of Positive Psychology, 11(3), 276-285.

8. Sasanpour, M., Khodabakhshi, M., \& Kh, N. (2012). The relationship between emotional intelligence, happiness and mental health in students of medical sciences of Isfahan University. International Journal of Collaborative Research on Internal Medicine \& Public Health, 4(9), 0-0.

9. Schutte, N. S., Malouff, J. M., Simunek, M., McKenley, J., \& Hollander, S. (2002). Characteristic emotional intelligence and emotional well-being. Cognition \& Emotion, 16(6), 769-785.

10. Smith, K. B., Profetto-McGrath, J., \& Cummings, G. G. (2009). Emotional intelligence and nursing: An integrative literature review. International journal of nursing studies, 46(12), 1624-1636.

Ubaidi, A. (2018). Is Emotional Intelligence a Need Skill for Health Care Provider. J Fam Med Dis Prev, 4(1). 


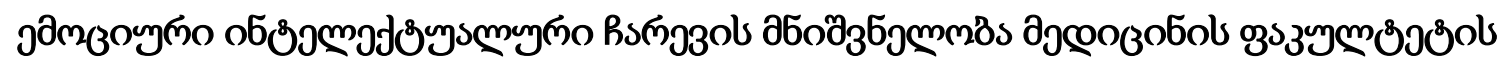

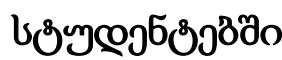

\author{
3ங்
}

Corresponding Author: Pramila Thapa, Nepal, 00977, Yeti Health Science Academy, pbrt426@gmail.com

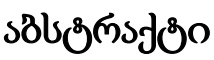

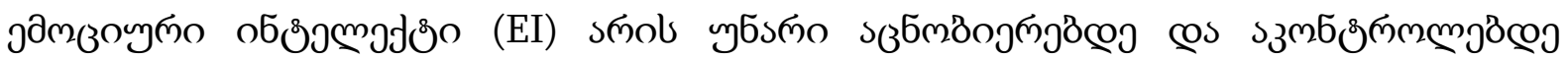

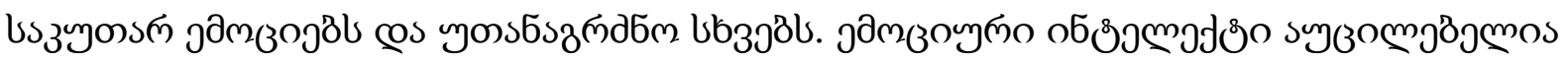

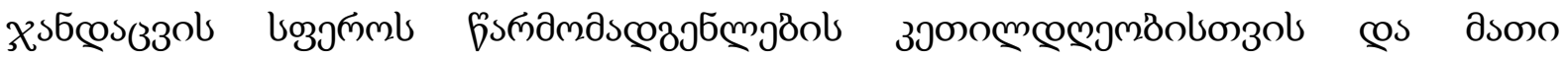

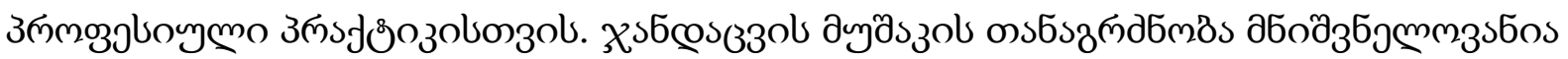

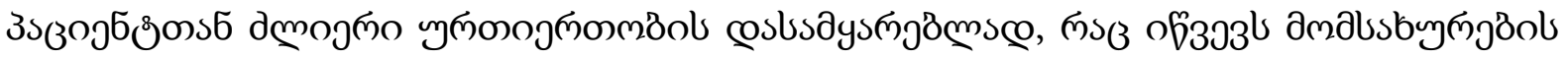

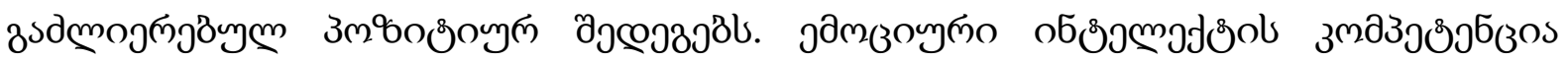

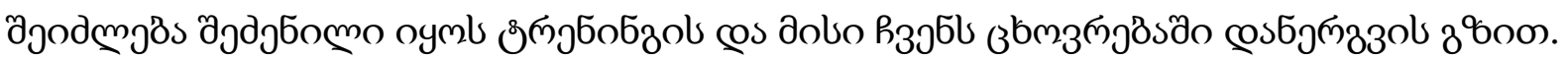

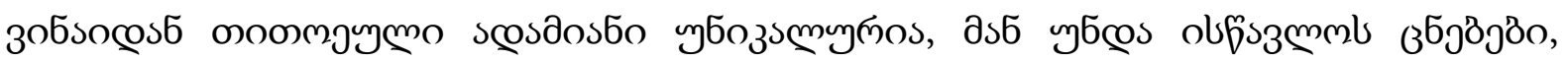

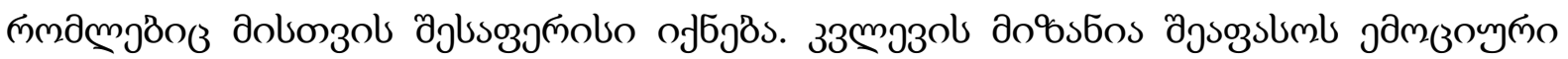

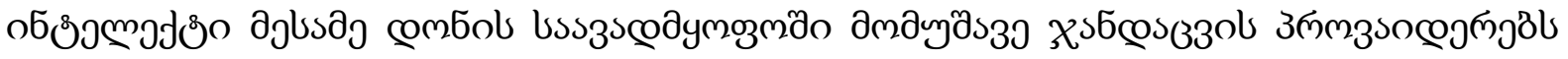

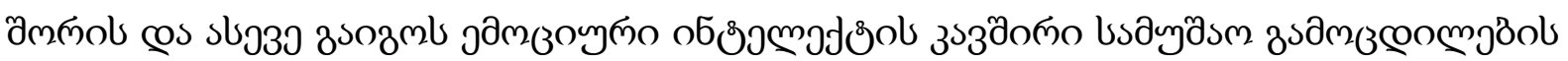

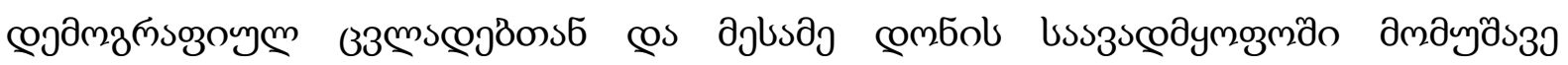

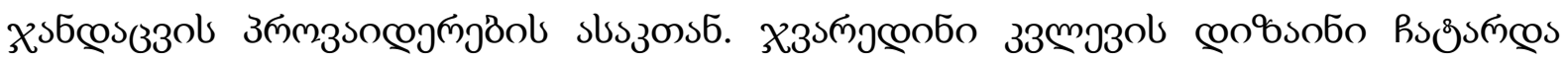

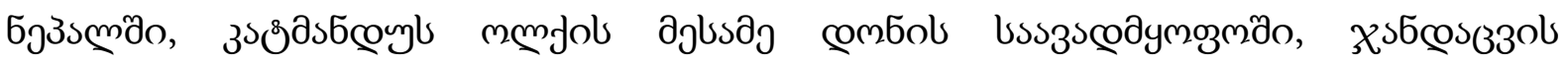

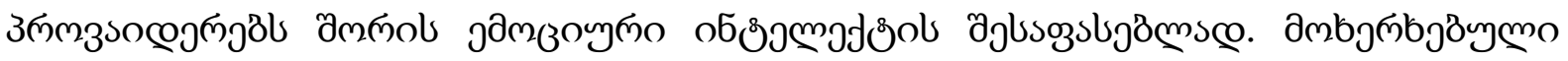

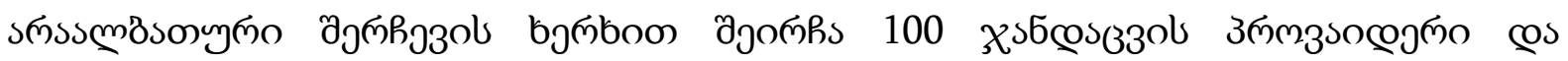

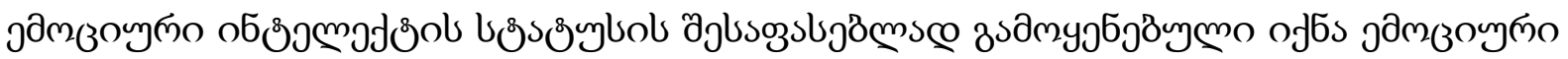

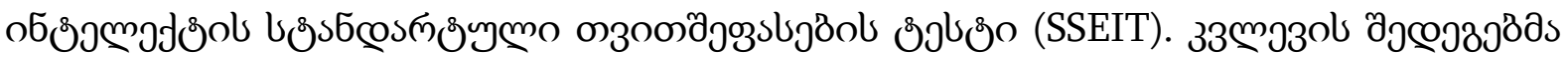

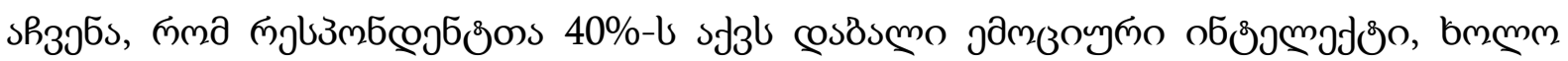

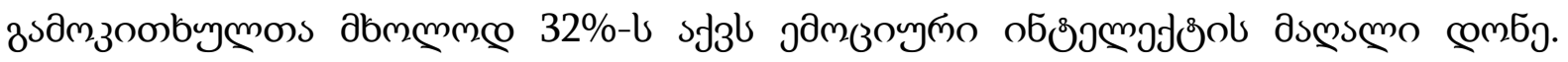

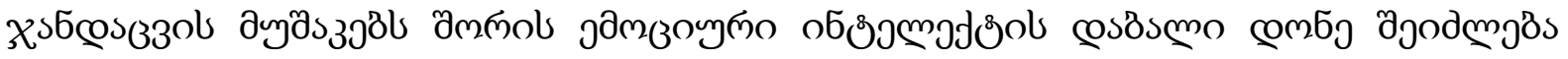

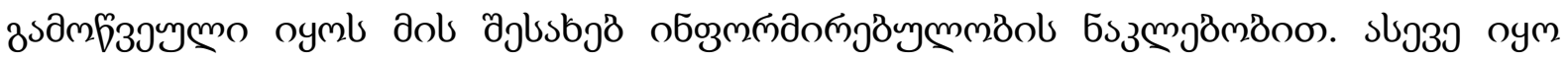

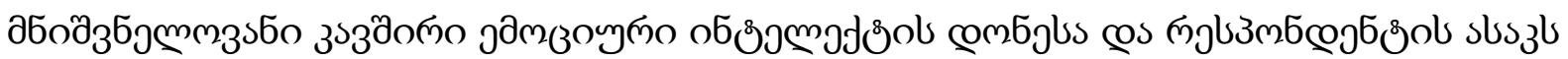
дмпо (

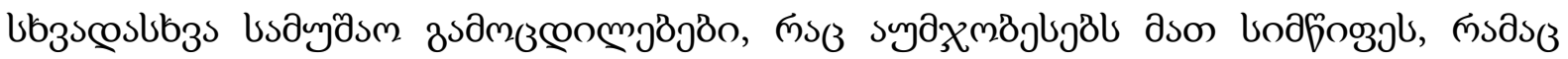

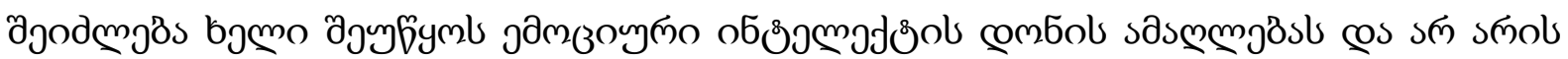

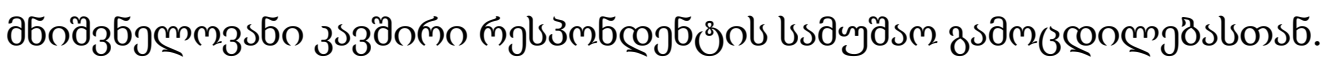

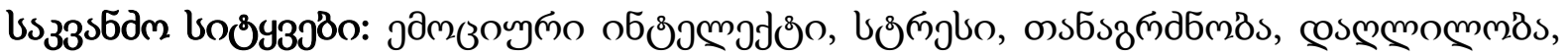

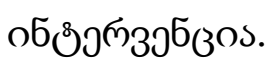




\title{
Эмоциональный интеллект медищинских работников, работающих в больнище третичного уровня
}

\author{
Прамила Тхапа, Рамеш Бхатта, Джосана Кханал, Анил Чаудхари
}

Corresponding Author: Pramila Thapa, Nepal, 00977, Yeti Health Science Academy, pbrt426@gmail.com

\section{Абстракт}

Эмоциональный интеллект (ЭИ) - это способность осознавать и контролировать свои эмоции и сопереживать другим. ЕІ имеет важное значение для благополучия врача и его профессиональной деятельности. Сочувствие медицинского работника важно для построения прочных отношений с пациентом, что приводит к улучшению положительных результатов обслуживания. Компетентность в области эмоционального интеллекта может быть приобретена путем обучения и применения в нашей собственной жизни. Поскольку каждый человек уникален, ему или ей необходимо изучить концепции, которые будут ему подходить. Целью исследования является оценка эмоционального интеллекта среди медицинских работников, работающих в больнице третичного уровня, а также понимание связи эмоционального интеллекта с демографическими переменными опыта работы и возрастом медицинских работников, работающих в больнице третичного уровня. Описательный кросс-секционный план исследования был проведен в больнице третичного уровня округа Катманду, Непал, для оценки эмоционального интеллекта среди медицинских работников. Благодаря удобному методу не вероятностной выборки было отобрано 100 поставщиков медицинских услуг, и для оценки состояния эмоционального интеллекта был использован стандартный тест эмоционального интеллекта с самоотчетом (SSEIT). Результаты исследования показали, что самые высокие сорок процентов респондентов обладают низким уровнем эмоционального интеллекта и только 32 процента респондентов обладают высоким уровнем эмоционального интеллекта. Более низкий уровень ЕI среди медицинских работников может быть связан с недостаточной осведомленностью об EI. Также была значимая связь между уровнем эмоционального интеллекта и возрастом респондента ( $\mathrm{p}=0,003)$. который показывает, что с возрастом люди имеют различные рабочие воздействия, которые улучшаются по мере их зрелости, что может способствовать повышению уровня EI, и нет существенной связи с опытом работы респондента.

Ключевые слова: эмоциональный интеллект, стресс, сострадание, усталость, вмешательство. 